\title{
ANALISIS INTERAKSI TEMAN SEBAYA PESERTA DIDIK KELAS V DI SDN NGARINGAN 05 KECAMATAN GANDUSARI KABUPATEN BLITAR
}

\author{
Yusvidha Ernata ${ }^{1)}$ \\ Pendidikan Jasmani Kesehatan dan Rekeasi \\ Fakultas Pendidikan Ilmu Eksakta dan Keolahragaan \\ IKIP Budi Utomo Malang \\ Email: 1yusvidha_ernata@yahoo.co.id
}

\begin{abstract}
Abstrak
Penelitian ini bertujuan untuk mengetahui interaksi teman sebaya pada peserta didik mengenai aspek-aspek antara lain: 1) Kelekatan pertemanan; 2) Posisi anak dalam kelompok sebaya. Penelitian ini menggunakan pendekatan kuantitatif deskriptif. Hasil dari penelitian ini mengakatakan bahwa ada beberapa indikator interaksi teman sebaya yang masih perlu diperhatikan untuk ditingkatkan antara lain: 1). bercerita kepada teman jika dimarahi orangtua yang memperoleh poin di bawah rata-rata yaitu 1,$5 ; 2$ ) teman-teman suka mengejek yang memperoleh poin di bawah rata-rata yaitu 1,$8 ; 3$ ) mempunyai geng di sekolah yang memperoleh poin di bawah rata-rata yaitu 1,$8 ; 4)$. tidak takut mengejek orang yang lebih dewasa ketika bersama teman-temanmemperoleh poin di bawah rata-rata yaitu 1,$3 ; 5)$ mengikuti ajakan teman-teman karena takut dijauhi yang memperoleh poin di bawah rata-rata yaitu $1,6 ; 6)$ ketika istirahat lebih senang di kelas yang memperoleh poin di bawah ratarata yaitu 2 ; 7) hanya bermain dengan teman yang dekat dengan saja yang memperoleh poin di bawah rata-rata yaitu 1,$8 ; 8$ ), ketika istirahat saya lebih senang di kelas yang memperoleh poin di bawah rata-rata yaitu 2 ;9) teman-teman memilih menjadi ketua jika mendapatkan tugas kelompok yang memperoleh poin di bawah rata-rata yaitu 2 ; 10) suka bermain sendiri di sekolah yang memperoleh poin di bawah rata-rata yaitu 1,$4 ; 11)$ teman-teman suka mengejek yang memperoleh poin di bawah rata-rata yatu 1,$8 ; 12)$ teman-teman mengajak menjadi anggota kelompok yang memperoleh poin di bawah rata-rata yaitu 2,7 .
\end{abstract}

Kata kunci: interaksi, teman sebaya, peserta didik

\begin{abstract}
This study aims to determine peer interaction among students about aspects among others: 1) Stickiness friendship; 2) The position of children in the same age group. This research uses descriptive quantitative approach. Results of this study was saying that there are some indicators of peer interaction that still need to be considered for improvement include: 1). tell a friend if scolded parents who earn points below the average of 1.5 ; 2) friends of ridicule who earn points below the average at 1.8; 3) have gangs in schools earn points below the average at 1.8; 4). not afraid to mock people who are more mature when with friends earn points below the average of $1.3 ; 5)$ follow the call of friends for fear of being shunned that earn points below the average at 1.6; 6) when the break is more fun in the classroom who earn points under the average is 2; 7) just playing with friends close by who earn
\end{abstract}

Yusvidha Ernata. Anaisis Interaksi Teman Sebaya Peserta Didik Kelas V Di SDN Ngaringan 05 Kecamatan Gandusari Kabupaten Blitar 
points below the average at 1.8; 8), when I break more fun in the classroom who earn points under the average is 2; 9) friends chose to become chairman if you get the task group earn points under the average is 2 ; 10) like to play alone at school earn points under the average is 1.4 ; 11) friends of ridicule who earn points below the average yatu 1.8; 12) friends to invite a member of the group who earn points under the average is 2.7 .

Keywords: interaction, peers, learners

\section{Pendahuluan}

Pendidikan di sekolah dasar merupakan pendidikan yang tepusat pada peserta didik kelas 1 sampai dengan kelas 6 anak yang berusia antara 7 sampai dengan 13 tahun yang dikembangkan sesuai dengan satuan pendidikan, potensi daerah/karakteristik daerah, sosial budaya masyarakat setempat bagi peserta didik. Dalam proses tersebut peserta didik menempuh berbagai bidang studi yang kesemuanya harus mampu dikuasai peserta didik. Tidaklah salah bila di sekolah dasar disebut sebagai pusat pendidikan. (Undang-undang No. 20 Tahun 2003 tentang Sistem Pendidikan Nasional) disebutkan, bahwa pengertian pendidikan adalah usaha sadar dan terencana yang tertuang ke dalam tujuan pendidikan nasional dan pendidikan di sekolah dasar yaitu, untuk mewujudkan suasana belajar dan proses kegiatan pembelajaran dengan tujuan agar peserta didik secara aktif mengembangkan potensi dirinya untuk memiliki kekuatan spiritual keagamaan, pengendalian diri, kepribadian, kecerdasan, akhlak mulia, serta keterampilan yang diperlukan dirinya dan masyarakat, dalam berbangsa dan bernegara.

Sedangkan Menurut Kamus Bahasa Indonesia, Kata pendidikan berasal dari kata 'didik' dan mendapat imbuhan 'pe' dan akhiran 'an', dari devinisi tersebut, maka dapat dijelaskan bahwa pendidikan mempunyai arti sebuah cara mendidik peserta didik atau memotivasi peserta didik untuk berperilaku baik dan membanggakan. bila dijelaskan secara spesifik, maka devinisi pendidikan adalah suatu proses pengubahan sikap dan perilaku seseorang atau kelompok orang dalam usaha mendewasakan manusia melalui upaya pengajaran atau pembelajaran. atau dapat disimpulkan usaha sadar untuk menyiapkan peserta didik melalui kegiatan bimbingan, pengajaran, dan atau latihan bagi peranannya di masa yang akan datang.

Sekolah merupakan system yang terstruktur, interaksi yang terjadi antar warga sekolah tentu tidak selamanya baik-baik saja, apalagi jika kita melihat fenomena-fenomena yang banyak terjadi di Negara Indonesia menganai perilaku menyimpang remaja di sekolah.

Yusvidha Ernata. Anaisis Interaksi Teman Sebaya Peserta Didik Kelas V Di SDN Ngaringan 05 Kecamatan Gandusari Kabupaten Blitar 
Hal ini berpengaruh terhadap sistem sekolah dan yang paling besar pengaruhnya yaitu terhadap pribadi dan masa depan peserta didik itu sendiri. (Purwitasari, 2011)

Lembaga pendidikan yang tidak kalah penting dengan sekolah adalah keluarga. Seorang individu tidak akan lepas dari keluarga sebagai lembaga pendidikan sepanjang hayatnya. Salam (2002) menyatakan bahwa, keluarga merupakan lembaga pendidikan yang pertama dan utama dan berlangsung secara wajar dan informal. Keluarga menjadi tempat seorang individu memulai berinteraksi dan menerima pendidikan. Keluarga mempunyai pengaruh yang sangat luas terhadap perkembangan anak dimana anak akan mendapatkan pengasuhan dan pendidikan sesuai karakteristik orang tua di dalam keluarga. Semua perilaku anak akan disesuaikan dengan aturan yang didapat dalam keluarga.

Segala keadaan yang ada dan diciptakan oleh keluarga akan menjadi bekal anak untuk keluar bersosialisasi dalam lingkungan yang lebih luas lagi. Lingkungan yang lebih luas dari keluarga adalah lingkungan sekitar anak mulai dari lingkungan tempat tinggalnya, lingkungan sekolahnya, dan lingkungan tempat bermainnya. Apa yang dipelajari anak dalam keluarga akan dibawa keluar dalam bersosialisasi.Anak mempelajari keterampilan emosi dari orang tua, kerabat, lingkungan sekitar. Pada masa kanak-kanak akhir, lingkungan sekitar amat mempengaruhi perkembangan emosi anak. Desmita (2007) menyatakan bahwa, anak usia 7-11 tahun meluangkan lebih dari 40\% waktunya untuk berinteraksi dengan teman sebaya.

Interaksi dengan teman sebaya merupakan salah satu sosialisasi yang dilakukan anak di luar lingkungan keluarga. Salah satu fungsi terpenting sebaya adalah memberikan sumber informasi dan perbandingan tentang dunia di luar keluarga (Santrock, 2007). Interaksi dengan teman sebaya akan memberikan pengalaman yang berbeda dari keluarga. Perbedaan pengalaman dalam keluarga dan di luar keluarga membuat anak beradaptasi dengan bantuan teman sebaya.

Interaksi teman sebaya pada masa kanak-kanak akhir ditandai olehpembentukan kelompok-kelompok kecil. Kelompok-kelompok kecil ini yang akan membuat anak mulai beradaptasi agar diterima oleh kelompok teman sebaya. Anak yang diterima dalam kelompok sebaya akan memiliki pengalaman emosi yang menyenangkan, begitu pula sebaliknya. Anak yang menarik diri, yang ditolak oleh sebaya dan merasa kesepian, memiliki resiko depresi. Anak-anak yang bersikap agresif terhadap teman sebaya mereka memiliki resiko mengalami 
beberapa masalah termasuk kenakalan remaja dan putus sekolah (Santrock, 2007).

Ahmadi (2002) menyatakan bahwa interaksi adalah suatu hubungan antara dua individu atau lebih, dimana kelakuan individu yang saling mempengaruhi, mengubah, atau memperbaiki kelakuan individu yang lain atau sebaliknya. Sebaya adalah orang dengan tingkat umur dan kedewasaan yang kira-kira sama (Santrock, 2007). Interaksi merupakan satu pertalian sosial antara individu yang bersangkutan saling mempengaruhi (Chaplin, 2006). Hetherington menyatakan bahwa teman sebaya sebagai sebuah kelompok sosial sering didefinisikan sebagai semua orang yang memiliki kesamaan sosial atau yang memiliki kesamaan ciri, seperti kesamaan sosial, atau yang memiliki kesamaan tingkat usia (Desmita, 2007). Interaksi teman sebaya adalah kontak yang intensif dengan teman-teman sebaya (Monks, 2002). Kelompok teman sebaya amat penting ketika anak memasuki masa kanak-kanak akhir. Kelompok teman sebaya merupakan kelompok bermain yang terbentuk secara alami di antara anak-anak yang tinggal berdekatan satu sama lain atau yang pergi sekolah bersama-sama. Kelompok teman sebaya seringkali terbentuk dari anak-anak yang memiliki ras atau asal suku bangsa yang sama dan status sosial ekonomi yang sama. Anak-anak yang bermain bersama biasanya usianya berdekatan dan berjenis kelamin sama.Berdasarkan uraian tersebut peneliti menyimpulkan interaksi teman sebaya adalah hubungan timbal balik antara dua individu atau lebih dengan tingkat umur yang berdekatan maupun tingkat kedewasaan hampir sama yang saling mempengaruhi, mengubah, memperbaiki perilaku atau sebaliknya. Pada masa kanak-kanak akhir peran teman sebaya dalam membentuk perilaku anak amat besar karena sebagian besar waktu anak dihabiskan dengan teman sebaya mereka. 


\section{METODE PENELITIAN}

Penelitian ini dilihat jenis data yang diperoleh dan analisis penelitian ini termasuk dalam penelitian kuantitatif deskriptif. Subyek dalam penelitian ini adalah peserta didik kelas V SD Negeri Ngaringan 05 Kecamatan Gandusari Kabupaten Blitar yang berjumlah 37 peserta didik.

Pengumpulan data dilakukan pada tanggal 6 Juni 2016 menggunakan skala dengan empat pilihan jawaban. Pengumpulan data dalam penelitian ini dimaksudkan untuk mengumpulkan data tentang interaksi teman sebaya. Instrumen yang akan digunakan dibuat berdasarkan kisi-kisi yang telah ditetapkan sebelumnya berdasarkan kajian teori yang telah disusun. Berikut ini kisi-kisi yang digunakan dalam penyusunan instrumen.

Tabel 1. Kisi-Kisi Interaksi Teman Sebaya

\begin{tabular}{|c|c|c|c|c|}
\hline Variabel & Aspek & Indikator & $\begin{array}{l}\text { No. } \\
\text { Butir }\end{array}$ & $\mathbf{J m l}$ \\
\hline \multirow{13}{*}{$\begin{array}{l}\text { Interaksi } \\
\text { teman } \\
\text { sebaya }\end{array}$} & \multirow{7}{*}{$\begin{array}{l}\text { Kelekatan } \\
\text { pertemanan }\end{array}$} & Kelekatan dengan sebaya & 2,10 & 2 \\
\hline & & $\begin{array}{l}\text { Menghabiskan banyak waktu } \\
\text { dengan sebaya }\end{array}$ & 17,21 & 2 \\
\hline & & $\begin{array}{l}\text { Mempunyai kelompok teman } \\
\text { sebaya }\end{array}$ & 5,24 & 2 \\
\hline & & Kepercayaan tinggi pada sebaya & $3,9,13$ & 3 \\
\hline & & $\begin{array}{l}\text { Ada aturan yang mengikat pada } \\
\text { pertemanan }\end{array}$ & 1,11 & 2 \\
\hline & & Mempengaruhi teman & 12,18 & 2 \\
\hline & & Keinginan identik dengan sebaya & 14,15 & 2 \\
\hline & \multirow{6}{*}{$\begin{array}{l}\text { Posisi anak } \\
\text { dalam } \\
\text { kelompok } \\
\text { sebaya }\end{array}$} & Banyak sedikit jumlah teman & 16,25 & 2 \\
\hline & & Suka menyendiri & 18,19 & 2 \\
\hline & & $\begin{array}{l}\text { Menjadi pemimpin kelompok di } \\
\text { sekolah }\end{array}$ & 4,6 & 2 \\
\hline & & Mendapat ajakan bemain teman & 22,23 & 2 \\
\hline & & Mendapat perlakuan baik teman & 17,20 & 2 \\
\hline & & $\begin{array}{l}\text { Mendapat teman dalam tugas } \\
\text { kelompok }\end{array}$ & 26,27 & 2 \\
\hline \multicolumn{3}{|r|}{ Jumlah } & & 27 \\
\hline
\end{tabular}

Yusvidha Ernata. Anaisis Interaksi Teman Sebaya Peserta Didik Kelas V Di SDN Ngaringan 05 Kecamatan Gandusari Kabupaten Blitar 


\section{PEMBAHASAN}

Berdasarkan analisis dikatakan bahwa ada beberapa aspek mengenaiinteraksi teman sebaya yang masih perlu diperhatikan untuk ditingkatkan antara lain:

Tabel 1. Kelekatan dengan Sebaya

\begin{tabular}{|c|c|c|c|c|c|c|}
\hline Indikator & Pernyataan & 4 & 3 & 2 & 1 & Rata-rata \\
\hline \multirow{4}{*}{$\begin{array}{l}\text { Kelekatan } \\
\text { dengan } \\
\text { sebaya }\end{array}$} & \multirow{2}{*}{$\begin{array}{l}\text { Saya bercerita } \\
\text { kepada teman } \\
\text { jika dimarahi } \\
\text { orangtua }\end{array}$} & 0 & 1 & 15 & 21 & \multirow[b]{2}{*}{1,5} \\
\hline & & $0 \%$ & $2,7 \%$ & $40,5 \%$ & $56,8 \%$ & \\
\hline & \multirow{2}{*}{$\begin{array}{l}\text { Saya } \\
\text { mengenal } \\
\text { teman-teman } \\
\text { saya dengan } \\
\text { baik }\end{array}$} & 30 & 5 & 2 & 0 & \multirow[b]{2}{*}{3,8} \\
\hline & & $81,1 \%$ & $13,5 \%$ & $5,4 \%$ & $0 \%$ & \\
\hline
\end{tabular}

Bercerita kepada teman jika dimarahi orangtua dalam tabel diperoleh nilai perhitungan rata-rata sebesar 1,5 termasuk dalam kategori kurang jika dibandingkan dengan rata-rata keseluruhan 2,7. Menurut perhitungan dalam tabel, diperoleh nilai frekwensi dan prosentase sangat baik sebesar $0(0 \%)$, frekwensi dan prosentase baik sebesar $1(2,7 \%)$, frekwensi dan prosentase cukup sebesar $15(40,5 \%)$, frekwensi dan prosentase kurang sebesar 21 (56,8\%). Hal ini menunjukkan bahwa Bercerita kepada teman jika dimarahi orangtua termasuk dalam kategori kurang meskipun rata-rata item ini sebesar 1,5 .

Mengenal teman-teman saya dengan baik dalam tabel diperoleh nilai perhitungan rata-rata sebesar 3,8 termasuk dalam kategori sangat baik jika dibandingkan dengan rata-rata keseluruhan 2,7. Menurut perhitungan dalam tabel, diperoleh nilai frekwensi dan prosentase sangat baik sebesar $30(81,1 \%)$, frekwensi dan prosentase baik sebesar $5(13,5 \%)$, frekwensi dan prosentase cukup sebesar $2(5,4 \%)$, frekwensi dan prosentase kurang sebesar $0(0 \%)$. Hal ini menunjukkan bahwa mengenal teman-teman saya dengan baik termasuk dalam kategori sangat baik meskipun rata-rata item ini sebesar 3,8. 
Tabel 2. Menghabiskan Banyak Waktu dengan Sebaya

\begin{tabular}{|c|c|c|c|c|c|c|}
\hline Indikator & Pernyataan & SL & $\mathbf{S}$ & $\mathbf{K}$ & $\mathbf{T P}$ & Rata-rata \\
\hline \multirow{4}{*}{$\begin{array}{l}\text { Menghabi } \\
\text { skan } \\
\text { banyak } \\
\text { waktu } \\
\text { dengan } \\
\text { sebaya }\end{array}$} & \multirow{2}{*}{$\begin{array}{l}\text { Teman-teman } \\
\text { suka mengejek } \\
\text { saya }\end{array}$} & 1 & 5 & 15 & 16 & \multirow[b]{2}{*}{1,8} \\
\hline & & $2,7 \%$ & $\begin{array}{c}13,5 \\
\%\end{array}$ & $\begin{array}{c}40,5 \\
\%\end{array}$ & $\begin{array}{c}43,2 \\
\%\end{array}$ & \\
\hline & \multirow{2}{*}{$\begin{array}{l}\text { Setiap hari saya } \\
\text { bermain } \\
\text { dengan teman- } \\
\text { teman }\end{array}$} & 18 & 12 & 6 & 1 & \multirow[b]{2}{*}{3,3} \\
\hline & & $\begin{array}{c}48,6 \\
\%\end{array}$ & $\begin{array}{c}32,4 \\
\%\end{array}$ & $\begin{array}{c}16,2 \\
\%\end{array}$ & $\begin{array}{c}2,7 \\
\%\end{array}$ & \\
\hline
\end{tabular}

Teman-teman suka mengejek dalam tabel diperoleh nilai perhitungan rata-rata sebesar 1,8 termasuk dalam kategori kurang jika dibandingkan dengan rata-rata keseluruhan 2,6. Menurut perhitungan dalam tabel, diperoleh nilai frekwensi dan prosentase sangat baik sebesar $1(2,7 \%)$, frekwensi dan prosentase baik sebesar $5(13,5 \%)$, frekwensi dan prosentase cukup sebesar 15 (40,5\%), frekwensi dan prosentase kurang sebesar 16 (43,2\%). Hal ini menunjukkan bahwa teman-teman suka mengejek termasuk dalam kategori kurang meskipun rata-rata item ini sebesar 1,8.

Setiap hari bermain dengan teman-temandalam tabel diperoleh nilai perhitungan rata-rata sebesar 3,3 termasuk dalam kategori sangat sangat baik jika dibandingkan dengan rata-rata keseluruhan 2,6. Menurut perhitungan dalam tabel, diperoleh nilai frekwensi dan prosentase sangat baik sebesar $18(48,6 \%)$, frekwensi dan prosentase baik sebesar $12(32,4 \%)$, frekwensi dan prosentase cukup sebesar 6 $(16,2 \%)$, frekwensi dan prosentase kurang sebesar 1 (2,7\%). Hal ini menunjukkan bahwa Setiap hari bermain dengan teman-teman termasuk dalam kategori sangat baik meskipun rata-rata item ini sebesar 3,3. 
Tabel 3. Mempunyai Kelompok Teman Sebaya

\begin{tabular}{|c|c|c|c|c|c|c|}
\hline Indikator & Pernyataan & SL & $\mathbf{S}$ & $\mathbf{K}$ & TP & Rata-rata \\
\hline \multirow{4}{*}{$\begin{array}{l}\text { Punyai } \\
\text { kelompok } \\
\text { teman } \\
\text { sebaya }\end{array}$} & \multirow{2}{*}{$\begin{array}{l}\text { Saya } \\
\text { mempunyai } \\
\text { geng di } \\
\text { sekolah } \\
\end{array}$} & 7 & 2 & 6 & 22 & \multirow[b]{2}{*}{1,8} \\
\hline & & $\begin{array}{c}18,9 \\
\%\end{array}$ & $\begin{array}{l}5,4 \\
\%\end{array}$ & $\begin{array}{c}16,2 \\
\%\end{array}$ & $\begin{array}{c}59,5 \\
\%\end{array}$ & \\
\hline & \multirow{2}{*}{$\begin{array}{l}\text { Saya suka } \\
\text { berkelompo } \\
\text { k dengan } \\
\text { teman- } \\
\text { teman } \\
\end{array}$} & 19 & 10 & 7 & 1 & \multirow[b]{2}{*}{3,3} \\
\hline & & $\begin{array}{c}51,4 \\
\%\end{array}$ & $27 \%$ & $\begin{array}{c}18,9 \\
\%\end{array}$ & $2,7 \%$ & \\
\hline
\end{tabular}

Mempunyai geng di sekolahdalam tabel diperoleh nilai perhitungan rata-rata sebesar 1,8 termasuk dalam kategori kurang jika dibandingkan dengan rata-rata keseluruhan 2,6. Menurut perhitungan dalam tabel, diperoleh nilai frekwensi dan prosentase sangat baik sebesar $7(18,9 \%)$, frekwensi dan prosentase baik sebesar $2(5,4 \%)$, frekwensi dan prosentase cukup sebesar $6(16,2 \%)$, frekwensi dan prosentase kurang sebesar $22(59,5 \%)$. Hal ini menunjukkan bahwa mempunyai geng di sekolah termasuk dalam kategori kurang meskipun rata-rata item ini sebesar 1,8 .

Suka berkelompok dengan teman-temandalam tabel diperoleh nilai perhitungan rata-rata sebesar 3,3 termasuk dalam kategori sangat baik jika dibandingkan dengan rata-rata keseluruhan 2,6. Menurut perhitungan dalam tabel, diperoleh nilai frekwensi dan prosentase sangat baik sebesar $19(51,4 \%)$, frekwensi dan prosentase baik sebesar $10(27 \%)$, frekwensi dan prosentase cukup sebesar 7(18,9\%), frekwensi dan prosentase kurang sebesar $1(2,7 \%)$. Hal ini menunjukkan bahwa suka berkelompok dengan teman-teman termasuk dalam kategori sangat baik meskipun rata-rata item ini sebesar 3,3. 
Tabel 4. Kepercayaan Tinggi pada Sebaya

\begin{tabular}{|c|c|c|c|c|c|c|}
\hline Indikator & Pernyataan & SL & $\mathrm{S}$ & $\mathrm{K}$ & $\mathrm{TP}$ & Rata-rata \\
\hline \multirow{6}{*}{$\begin{array}{l}\text { Percaya } \\
\text { tinggi } \\
\text { pada } \\
\text { sebaya }\end{array}$} & \multirow{2}{*}{$\begin{array}{l}\text { Saya percaya } \\
\text { apa yang } \\
\text { dikatakan } \\
\text { teman-teman } \\
\text { itu benar }\end{array}$} & 1 & 3 & 31 & 2 & \multirow[b]{2}{*}{2,1} \\
\hline & & $2,7 \%$ & $\begin{array}{c}8,1 \\
\%\end{array}$ & $\begin{array}{c}83,8 \\
\%\end{array}$ & $5,4 \%$ & \\
\hline & \multirow[b]{2}{*}{$\begin{array}{l}\text { saya tidak takut } \\
\text { mengejek } \\
\text { orang yang } \\
\text { lebih dewasa } \\
\text { ketika bersama } \\
\text { teman-teman }\end{array}$} & 0 & 1 & 8 & 28 & \multirow[b]{2}{*}{1,3} \\
\hline & & $0 \%$ & $\begin{array}{c}2,7 \\
\%\end{array}$ & $\begin{array}{c}21,6 \\
\%\end{array}$ & $\begin{array}{c}75,7 \\
\%\end{array}$ & \\
\hline & \multirow{2}{*}{$\begin{array}{l}\text { Saya } \\
\text { menceritakan } \\
\text { rahasia kepada } \\
\text { teman-teman } \\
\text { dekat saya }\end{array}$} & 8 & 2 & 18 & 9 & \multirow[b]{2}{*}{2,2} \\
\hline & & $\begin{array}{c}21,6 \\
\%\end{array}$ & $\begin{array}{c}5,4 \\
\%\end{array}$ & $\begin{array}{c}48,6 \\
\%\end{array}$ & $\begin{array}{c}24,3 \\
\%\end{array}$ & \\
\hline
\end{tabular}

Percaya apa yang dikatakan teman-teman itu benar dalam tabel diperoleh nilai perhitungan rata-rata sebesar 2,1 termasuk dalam kategori sangat baik jika dibandingkan dengan rata-rata keseluruhan 1,9. Menurut perhitungan dalam tabel, diperoleh nilai frekwensi dan prosentase sangat baik sebesar $1(2,7 \%)$, frekwensi dan prosentase baik sebesar $3(8,1 \%)$, frekwensi dan prosentase cukup sebesar $31(83,8 \%)$, frekwensi dan prosentase kurang sebesar 2 (5,4\%). Hal ini menunjukkan bahwa percaya apa yang dikatakan teman-teman itu benar termasuk dalam kategori sangat baik meskipun rata-rata item ini sebesar 2,1 .

Tidak takut mengejek orang yang lebih dewasa ketika bersama teman-temandalam tabel diperoleh nilai perhitungan rata-rata sebesar 1,3 termasuk dalam kategori kurang jika dibandingkan dengan rata-rata keseluruhan 1,9. Menurut perhitungan dalam tabel, diperoleh nilai frekwensi dan prosentase sangat baik sebesar $0(0 \%)$, frekwensi dan prosentase baik sebesar $1(2,7 \%)$, frekwensi dan prosentase cukup sebesar 8(21,6\%), frekwensi dan prosentase kurang sebesar $28(75,7 \%)$. Hal ini menunjukkan bahwa tidak takut mengejek orang yang lebih dewasa ketika bersama teman-temantermasuk dalam kategori kurang meskipun rata-rata item ini sebesar 1,3. 
Menceritakan rahasia kepada teman-teman dekat dalam tabel diperoleh nilai perhitungan rata-rata sebesar 2,2 termasuk dalam kategori sangat baik jika dibandingkan dengan rata-rata keseluruhan 1,9. Menurut perhitungan dalam tabel, diperoleh nilai frekwensi dan prosentase sangat baik sebesar $8(21,6 \%)$, frekwensi dan prosentase baik sebesar $2(5,4 \%)$, frekwensi dan prosentase cukup sebesar 8 $(21,6 \%)$, frekwensi dan prosentase kurang sebesar 9 (24,3\%). Hal ini menunjukkan bahwa menceritakan rahasia kepada teman-teman dekat termasuk dalam kategori sangat baik meskipun rata-rata item ini sebesar 2,2.

Tabel 5. Ada Aturan yang Mengikat pada Pertemanan

\begin{tabular}{|c|c|c|c|c|c|c|}
\hline Indikator & Pernyataan & SL & $\mathrm{S}$ & $\mathrm{K}$ & $\mathrm{TP}$ & Rata-rata \\
\hline \multirow{4}{*}{$\begin{array}{l}\text { Ada aturan } \\
\text { yang } \\
\text { mengikat } \\
\text { pada } \\
\text { pertemanan }\end{array}$} & \multirow[b]{2}{*}{$\begin{array}{l}\text { Saya } \\
\text { dilarang } \\
\text { bermain } \\
\text { dengan } \\
\text { teman yang } \\
\text { dibenci } \\
\text { teman saya }\end{array}$} & 1 & 3 & 17 & 16 & \\
\hline & & $2,7 \%$ & $8,1 \%$ & $45,9 \%$ & $43,2 \%$ & 1,7 \\
\hline & \multirow[b]{2}{*}{$\begin{array}{l}\text { Saya } \\
\text { mengikuti } \\
\text { ajakan } \\
\text { teman-teman } \\
\text { karena takut } \\
\text { dijauhi }\end{array}$} & 1 & 3 & 15 & 18 & \\
\hline & & $2,7 \%$ & $8,1 \%$ & $40,5 \%$ & $48,6 \%$ & 1,6 \\
\hline
\end{tabular}

Dilarang bermain dengan teman yang dibenci teman dalam tabel diperoleh nilai perhitungan rata-rata sebesar 1,7 termasuk dalam kategori baik jika dibandingkan dengan rata-rata keseluruhan 1,7. Menurut perhitungan dalam tabel, diperoleh nilai frekwensi dan prosentase sangat baik sebesar $1(2,7 \%)$, frekwensi dan prosentase baik sebesar $3(8,1 \%)$, frekwensi dan prosentase cukup sebesar $17(45,9 \%)$, frekwensi dan prosentase kurang sebesar 16 (43,2\%). Hal ini menunjukkan bahwa dilarang bermain dengan teman yang dibenci temantermasuk dalam kategori baik meskipun rata-rata item ini sebesar 1,7 .

Mengikuti ajakan teman-teman karena takut dijauhidalam tabel diperoleh nilai perhitungan rata-rata sebesar 1,6termasuk dalam kategori kurang jika dibandingkan dengan rata-rata keseluruhan 1,7. 
Menurut perhitungan dalam tabel, diperoleh nilai frekwensi dan prosentase sangat baik sebesar $1(2,7 \%)$, frekwensi dan prosentase baik sebesar $3(8,1 \%)$, frekwensi dan prosentase cukup sebesar 15(40,5\%), frekwensi dan prosentase kurang sebesar 18 (48,6\%). Hal ini menunjukkan bahwa mengikuti ajakan teman-teman karena takut dijauhitermasuk dalam kategori kurang meskipun rata-rata item ini sebesar 1,6.

Tabel 6. Mempengaruhi Teman

\begin{tabular}{|c|c|c|c|c|c|c|}
\hline Indikator & Pernyataan & SL & $\mathrm{S}$ & $\mathrm{K}$ & $\mathrm{TP}$ & Rata-rata \\
\hline \multirow{4}{*}{$\begin{array}{l}\text { Mempengaruhi } \\
\text { teman }\end{array}$} & \multirow{2}{*}{$\begin{array}{l}\text { Teman- } \\
\text { teman mau } \\
\text { saya ajak } \\
\text { bermain }\end{array}$} & 10 & 13 & 13 & 1 & \multirow[b]{2}{*}{2,9} \\
\hline & & $27 \%$ & $\begin{array}{c}35,1 \\
\%\end{array}$ & $\begin{array}{c}35,1 \\
\%\end{array}$ & $2,7 \%$ & \\
\hline & \multirow{2}{*}{$\begin{array}{l}\text { Ketika } \\
\text { istirahat } \\
\text { saya lebih } \\
\text { senang di } \\
\text { kelas }\end{array}$} & 1 & 6 & 21 & 9 & \multirow[b]{2}{*}{2} \\
\hline & & $\begin{array}{c}2,7 \\
\%\end{array}$ & $\begin{array}{c}16,2 \\
\%\end{array}$ & $\begin{array}{c}56,8 \\
\%\end{array}$ & $\begin{array}{c}24,3 \\
\%\end{array}$ & \\
\hline
\end{tabular}

Teman-teman mau saya diiajak bermain dalam tabel diperoleh nilai perhitungan rata-rata sebesar 2,9 termasuk dalam kategori sangat baik jika dibandingkan dengan rata-rata keseluruhan 2,5. Menurut perhitungan dalam tabel, diperoleh nilai frekwensi dan prosentase sangat baik sebesar $10(27 \%)$, frekwensi dan prosentase baik sebesar 13 $(35,1 \%)$, frekwensi dan prosentase cukup sebesar $13(35,1 \%)$, frekwensi dan prosentase kurang sebesar 1 (2,7\%). Hal ini menunjukkan bahwa Teman-teman mau saya ajak bermain termasuk dalam kategori sangat baik meskipun rata-rata item ini sebesar 2,9.

Ketika istirahat lebih senang di kelas dalam tabel diperoleh nilai perhitungan rata-rata sebesar 2 termasuk dalam kategori kurang jika dibandingkan dengan rata-rata keseluruhan 2,5. Menurut perhitungan dalam tabel, diperoleh nilai frekwensi dan prosentase sangat baik sebesar $1(2,7 \%)$, frekwensi dan prosentase baik sebesar $6(16,2 \%)$, frekwensi dan prosentase cukup sebesar 21(56,8\%), frekwensi dan prosentase kurang sebesar $9(24,3 \%)$. Hal ini menunjukkan bahwa Ketika istirahat lebih senang di kelas termasuk dalam kategori kurang meskipun rata-rata item ini sebesar 2,5. 
Tabel 7. Keinginan Identik dengan Sebaya

\begin{tabular}{|c|c|c|c|c|c|c|}
\hline Indikator & Pernyataan & $\mathrm{SL}$ & $\mathrm{S}$ & $\mathrm{K}$ & $\mathrm{TP}$ & Rata-rata \\
\hline \multirow{4}{*}{$\begin{array}{l}\text { Keingina } \\
\mathrm{n} \text { identik } \\
\text { dengan } \\
\text { sebaya }\end{array}$} & \multirow[b]{2}{*}{$\begin{array}{l}\text { Saya memakai } \\
\text { pakaian atau } \\
\text { aksesoris yang } \\
\text { sama atau } \\
\text { mirip dengan } \\
\text { teman-teman } \\
\text { kelompok } \\
\text { bermain }\end{array}$} & 0 & 6 & 10 & 21 & \\
\hline & & $0 \%$ & $\begin{array}{c}16,2 \\
\%\end{array}$ & $27 \%$ & $\begin{array}{c}56,8 \\
\%\end{array}$ & 1,6 \\
\hline & \multirow{2}{*}{$\begin{array}{l}\text { Saya ingin } \\
\text { memiliki } \\
\text { barang yang } \\
\text { sama dengan } \\
\text { teman-teman }\end{array}$} & 1 & 0 & 18 & 18 & \\
\hline & & $2,7 \%$ & $0 \%$ & $\begin{array}{c}48,6 \\
\%\end{array}$ & $\begin{array}{c}48,6 \\
\%\end{array}$ & 1,6 \\
\hline
\end{tabular}

Memakai pakaian atau aksesoris yang sama atau mirip dengan teman-teman kelompok bermain dalam tabel diperoleh nilai perhitungan rata-rata sebesar 1,6 termasuk dalam kategori baik jika dibandingkan dengan rata-rata keseluruhan 1,6. Menurut perhitungan dalam tabel, diperoleh nilai frekwensi dan prosentase sangat baik sebesar $0(0 \%)$, frekwensi dan prosentase baik sebesar $6(16,2 \%)$, frekwensi dan prosentase cukup sebesar 10 (27\%), frekwensi dan prosentase kurang sebesar $21(56,8 \%)$. Hal ini menunjukkan bahwa memakai pakaian atau aksesoris yang sama atau mirip dengan temanteman kelompok bermaintermasuk dalam kategori baik meskipun ratarata item ini sebesar 1,6.

Ingin memiliki barang yang sama dengan teman-temandalam tabel diperoleh nilai perhitungan rata-rata sebesar 1,6 termasuk dalam kategori baik jika dibandingkan dengan rata-rata keseluruhan 1,6. Menurut perhitungan dalam tabel, diperoleh nilai frekwensi dan prosentase sangat baik sebesar $1(2,7 \%)$, frekwensi dan prosentase baik sebesar $0(0 \%)$, frekwensi dan prosentase cukup sebesar 18(48,6\%), frekwensi dan prosentase kurang sebesar 18 (48,6\%). Hal ini menunjukkan bahwa ingin memiliki barang yang sama dengan temantemantermasuk dalam kategori baik meskipun rata-rata item ini sebesar 1,6 . 
Tabel 8. Banyak Sedikit Jumlah Teman

\begin{tabular}{|c|c|c|c|c|c|c|}
\hline Indikator & Pernyataan & $\mathrm{SL}$ & $\mathrm{S}$ & $\mathrm{K}$ & $\mathrm{TP}$ & Rata-rata \\
\hline \multirow{4}{*}{$\begin{array}{l}\text { Banyak } \\
\text { sedikit } \\
\text { jumlah } \\
\text { teman }\end{array}$} & \multirow{2}{*}{$\begin{array}{l}\text { Saya hanya } \\
\text { bermain } \\
\text { dengan teman } \\
\text { yang dekat } \\
\text { dengan saya } \\
\text { saja }\end{array}$} & 2 & 8 & 6 & 21 & \\
\hline & & $5,4 \%$ & $21,6 \%$ & $16,2 \%$ & 56,8 & 1,8 \\
\hline & \multirow{2}{*}{$\begin{array}{l}\text { Saya bermain } \\
\text { dengan teman } \\
\text { sekelas } \\
\text { maupun beda } \\
\text { kelas }\end{array}$} & 15 & 8 & 14 & 0 & \\
\hline & & $40,5 \%$ & $21,6 \%$ & $37,8 \%$ & $0 \%$ & 3 \\
\hline
\end{tabular}

Hanya bermain dengan teman yang dekat dengan saja dalam tabel diperoleh nilai perhitungan rata-rata sebesar 1,8 termasuk dalam kategori sangat baik jika dibandingkan dengan rata-rata keseluruhan 2,4. Menurut perhitungan dalam tabel, diperoleh nilai frekwensi dan prosentase sangat baik sebesar $2(5,4 \%)$, frekwensi dan prosentase baik sebesar $8(21,6 \%)$, frekwensi dan prosentase cukup sebesar $6(16,2 \%)$, frekwensi dan prosentase kurang sebesar 21 (56,8\%). Hal ini menunjukkan bahwa hanya bermain dengan teman yang dekat dengan saya sajatermasuk dalam kategori sangat baik meskipun rata-rata item ini sebesar 1,8 .

Bermain dengan teman sekelas maupun beda kelas dalam tabel diperoleh nilai perhitungan rata-rata sebesar 3 termasuk dalam kategori sangat baik jika dibandingkan dengan rata-rata keseluruhan 2,4. Menurut perhitungan dalam tabel, diperoleh nilai frekwensi dan prosentase sangat baik sebesar 15 (40,5\%), frekwensi dan prosentase baik sebesar 8 (21,6\%), frekwensi dan prosentase cukup sebesar 14(37,8\%), frekwensi dan prosentase kurang sebesar $0(0 \%)$. Hal ini menunjukkan bahwa bermain dengan teman sekelas maupun beda kelas termasuk dalam kategori sangat baik meskipun rata-rata item ini sebesar 3 . 
Tabel 9. Suka Menyendiri

\begin{tabular}{|c|l|c|c|c|c|c|}
\hline Indikator & Pernyataan & SL & S & K & TP & Rata-rata \\
\hline Suka \\
menyendiri & $\begin{array}{l}\text { Ketika } \\
\text { istirahat } \\
\text { saya lebih } \\
\text { senang di } \\
\text { kelas }\end{array}$ & 1 & 6 & 21 & 9 & \multirow{2}{*}{2} \\
\cline { 2 - 6 } & $\begin{array}{l}\text { Saya suka } \\
\text { belajar } \\
\text { sendiri } \\
\text { daripada } \\
\text { dengan } \\
\text { teman- } \\
\text { teman }\end{array}$ & $2,7 \%, 2 \%$ & $56,8 \%$ & $24,3 \%$ & 2 \\
\cline { 2 - 6 } & $5,4 \%$ & $45,9 \%$ & $24,3 \%$ & 2,1 \\
\hline
\end{tabular}

Ketika istirahat saya lebih senang di kelas dalam tabel diperoleh nilai perhitungan rata-rata sebesar 2termasuk dalam kategori kurang jika dibandingkan dengan rata-rata keseluruhan 2,1. Menurut perhitungan dalam tabel, diperoleh nilai frekwensi dan prosentase sangat baik sebesar $1(2,7 \%)$, frekwensi dan prosentase baik sebesar 6 $(16,2 \%)$, frekwensi dan prosentase cukup sebesar 21(56,8\%), frekwensi dan prosentase kurang sebesar $9(24,3 \%)$. Hal ini menunjukkan bahwa Ketika istirahat saya lebih senang di kelaster masuk dalam kategori kurang meskipun rata-rata item ini besar.

Suka belajar sendiri daripada dengan teman-temandalam tabel diperoleh nilai perhitungan rata-rata sebesar 2,1 termasuk dalam kategori baik jika dibandingkan dengan rata-rata keseluruhan 2,1. Menurut perhitungan dalam tabel, diperoleh nilai frekwensi dan prosentase sangat baik sebesar $2(5,4 \%)$, frekwensi dan prosentase baik sebesar $9(24,3 \%)$, frekwensi dan prosentase cukup sebesar 17(45,9\%), frekwensi dan prosentase kurang sebesar 9 (24,3\%). Hal ini menunjukkan bahwa suka belajar sendiri daripada dengan teman-teman termasuk dalam kategori baik meskipun rata-rata item ini sebesar 2,1. 
Tabel 10. Menjadi Pemimpin Kelompok di Sekolah

\begin{tabular}{|c|c|c|c|c|c|c|}
\hline Indikator & Pernyataan & SL & $\mathrm{S}$ & $\mathrm{K}$ & TP & Rata-rata \\
\hline \multirow{4}{*}{$\begin{array}{l}\text { Menjadi } \\
\text { pemimpin } \\
\text { kelompok } \\
\text { di sekolah }\end{array}$} & \multirow{2}{*}{$\begin{array}{l}\text { Saya lebih } \\
\text { suka menjadi } \\
\text { anggota } \\
\text { kelompok }\end{array}$} & 15 & 5 & 12 & 5 & \multirow[b]{2}{*}{2,8} \\
\hline & & $\begin{array}{c}40,5 \\
\%\end{array}$ & $\begin{array}{c}13,5 \\
\%\end{array}$ & $\begin{array}{c}32,4 \\
\%\end{array}$ & $\begin{array}{c}13,5 \\
\%\end{array}$ & \\
\hline & \multirow[b]{2}{*}{$\begin{array}{l}\text { Teman-teman } \\
\text { memilih saya } \\
\text { menjadi ketua } \\
\text { jika } \\
\text { mendapatkan } \\
\text { tugas } \\
\text { kelompok }\end{array}$} & 7 & 4 & 7 & 19 & \multirow[b]{2}{*}{2} \\
\hline & & $\begin{array}{c}18,9 \\
\%\end{array}$ & $\begin{array}{c}10,8 \\
\%\end{array}$ & $\begin{array}{c}18,9 \\
\%\end{array}$ & $\begin{array}{c}51,4 \\
\%\end{array}$ & \\
\hline
\end{tabular}

Lebih suka menjadi anggota kelompok dalam tabel diperoleh nilai perhitungan rata-rata sebesar 2,8 termasuk dalam kategori sangat baik jika dibandingkan dengan rata-rata keseluruhan 2,5. Menurut perhitungan dalam tabel, diperoleh nilai frekwensi dan prosentase sangat baik sebesar $15(40,5 \%)$, frekwensi dan prosentase baik sebesar $5(13,5 \%)$, frekwensi dan prosentase cukup sebesar $12(32,4 \%)$, frekwensi dan prosentase kurang sebesar 5 (13,5\%). Hal ini menunjukkan bahwa lebih suka menjadi anggota kelompoktermasuk dalam kategori sangat baik meskipun rata-rata item ini sebesar 2,8.

Teman-teman memilih menjadi ketua jika mendapatkan tugas kelompokdalam tabel diperoleh nilai perhitungan rata-rata sebesar 2 termasuk dalam kategori kurang jika dibandingkan dengan rata-rata keseluruhan 2,5. Menurut perhitungan dalam tabel, diperoleh nilai frekwensi dan prosentase sangat baik sebesar $7(18,9 \%)$, frekwensi dan prosentase baik sebesar $4(10,8 \%)$, frekwensi dan prosentase cukup sebesar 7(18,9\%), frekwensi dan prosentase kurang sebesar $19(51,4 \%)$. Hal ini menunjukkan bahwa Teman-teman memilih menjadi ketua jika mendapatkan tugas kelompoktermasuk dalam kategori kurang meskipun rata-rata item ini sebesar 2. 
Tabel 11. Mendapat Ajakan Bemain Teman

\begin{tabular}{|c|c|c|c|c|c|c|}
\hline Indikator & Pernyataan & $\mathrm{SL}$ & $\mathrm{S}$ & $\mathrm{K}$ & $\mathrm{TP}$ & Rata-rata \\
\hline \multirow{4}{*}{$\begin{array}{l}\text { Mendapat } \\
\text { ajakan } \\
\text { bemain } \\
\text { teman }\end{array}$} & \multirow{2}{*}{$\begin{array}{l}\text { Teman- } \\
\text { teman } \\
\text { mengajak } \\
\text { saya } \\
\text { bermain }\end{array}$} & 20 & 9 & 8 & 0 & \\
\hline & & $54,1 \%$ & $24,3 \%$ & $21,6 \%$ & $0 \%$ & 3,3 \\
\hline & \multirow{2}{*}{$\begin{array}{l}\text { Saya suka } \\
\text { bermain } \\
\text { sendiri di } \\
\text { sekolah }\end{array}$} & 1 & 3 & 4 & 29 & \multirow[b]{2}{*}{1,4} \\
\hline & & $2,7 \%$ & $8,1 \%$ & $10,8 \%$ & $78,4 \%$ & \\
\hline
\end{tabular}

Teman-teman mengajak saya bermain dalam tabel diperoleh nilai perhitungan rata-rata sebesar 3,3 termasuk dalam kategori sangat baik jika dibandingkan dengan rata-rata keseluruhan 1,9. Menurut perhitungan dalam tabel, diperoleh nilai frekwensi dan prosentase sangat baik sebesar $20(54,1 \%)$, frekwensi dan prosentase baik sebesar 9 (24,3\%), frekwensi dan prosentase cukup sebesar 8 (21,6\%), frekwensi dan prosentase kurang sebesar $0(0 \%)$. Hal ini menunjukkan bahwa Teman-teman mengajak saya bermain termasuk dalam kategori sangat baik meskipun rata-rata item ini sebesar 1,9.

Suka bermain sendiri di sekolahdalam tabel diperoleh nilai perhitungan rata-rata sebesar 1,4 termasuk dalam kategori kurang jika dibandingkan dengan rata-rata keseluruhan 1,9. Menurut perhitungan dalam tabel, diperoleh nilai frekwensi dan prosentase sangat baik sebesar $1(2,7 \%)$, frekwensi dan prosentase baik sebesar $3(8,1 \%)$, frekwensi dan prosentase cukup sebesar 4(10,8\%), frekwensi dan prosentase kurang sebesar $29(78.4 \%)$. Hal ini menunjukkan bahwa suka bermain sendiri di sekolahtermasuk dalam kategori kurang meskipun rata-rata item ini sebesar 1,9. 
Tabel 12. Mendapat Perlakuan Baik Teman

\begin{tabular}{|c|c|c|c|c|c|c|}
\hline Indikator & Pernyataan & SL & $\mathrm{S}$ & $\mathrm{K}$ & TP & Rata-rata \\
\hline \multirow{4}{*}{$\begin{array}{l}\text { Mendapat } \\
\text { perlakuan } \\
\text { baik teman }\end{array}$} & \multirow{2}{*}{$\begin{array}{l}\text { Teman-teman } \\
\text { suka } \\
\text { mengejek } \\
\text { saya }\end{array}$} & 1 & 5 & 15 & 16 & \multirow[b]{2}{*}{1,8} \\
\hline & & $2,7 \%$ & $13,5 \%$ & $40,5 \%$ & $43,2 \%$ & \\
\hline & \multirow{2}{*}{$\begin{array}{l}\text { Teman-teman } \\
\text { berbuat usil } \\
\text { atau } \\
\text { mengganggu } \\
\text { saya }\end{array}$} & 2 & 5 & 22 & 8 & \multirow[b]{2}{*}{2} \\
\hline & & $5,4 \%$ & $13,5 \%$ & $59,5 \%$ & $21,6 \%$ & \\
\hline
\end{tabular}

Teman-teman suka mengejek dalam tabel diperoleh nilai perhitungan rata-rata sebesar 1,8 termasuk dalam kategori kurang jika dibandingkan dengan rata-rata keseluruhan 1,9. Menurut perhitungan dalam tabel, diperoleh nilai frekwensi dan prosentase sangat baik sebesar $1(2,7 \%)$, frekwensi dan prosentase baik sebesar $5(13,5 \%)$, frekwensi dan prosentase cukup sebesar 15(40,5\%), frekwensi dan prosentase kurang sebesar $16(43,2 \%)$. Hal ini menunjukkan bahwa Teman-teman suka mengejek termasuk dalam kategori kurang meskipun rata-rata item ini sebesar 1,8 .

Teman-teman berbuat usil atau mengganggu dalam tabel diperoleh nilai perhitungan rata-rata sebesar 2 termasuk dalam kategori sangat baik jika dibandingkan dengan rata-rata keseluruhan 1,9. Menurut perhitungan dalam tabel, diperoleh nilai frekwensi dan prosentase sangat baik sebesar $2(5,4 \%)$, frekwensi dan prosentase baik sebesar 5 (13,5\%), frekwensi dan prosentase cukup sebesar 22(59,5\%), frekwensi dan prosentase kurang sebesar 8 (21,6\%). Hal ini menunjukkan bahwa Teman-teman berbuat usil atau mengganggu termasuk dalam kategori sangat baik meskipun rata-rata item ini sebesar 2 . 
Tabel 13. Mendapat Teman Dalam Tugas Kelompok

\begin{tabular}{|c|c|c|c|c|c|c|}
\hline Indikator & Pernyataan & SL & $\mathrm{S}$ & $\mathrm{K}$ & $\mathrm{TP}$ & Rata-rata \\
\hline \multirow{4}{*}{$\begin{array}{l}\text { Mendapat } \\
\text { teman } \\
\text { dalam } \\
\text { tugas } \\
\text { kelompok }\end{array}$} & \multirow[b]{2}{*}{$\begin{array}{l}\text { Saya selalu } \\
\text { mendapat } \\
\text { kelompok } \\
\text { ketika } \\
\text { mengerjakan } \\
\text { tugas } \\
\text { kelompok }\end{array}$} & 19 & 9 & 9 & 0 & \\
\hline & & $51,4 \%$ & $24,3 \%$ & $24,3 \%$ & $0 \%$ & 3,3 \\
\hline & \multirow[b]{2}{*}{$\begin{array}{l}\text { Teman-teman } \\
\text { mengajak } \\
\text { saya menjadi } \\
\text { anggota } \\
\text { kelompok } \\
\text { dalam } \\
\text { mengerjakan } \\
\text { tugas }\end{array}$} & 11 & 6 & 18 & 2 & \\
\hline & & $29,7 \%$ & $16,2 \%$ & $48,6 \%$ & $5,4 \%$ & 2,7 \\
\hline
\end{tabular}

Selalu mendapat kelompok ketika mengerjakan tugas kelompok dalam tabel diperoleh nilai perhitungan rata-rata sebesar 3,3 termasuk dalam kategori sangat baik jika dibandingkan dengan rata-rata keseluruhan 3. Menurut perhitungan dalam tabel, diperoleh nilai frekwensi dan prosentase sangat baik sebesar 19 (51,4\%), frekwensi dan prosentase baik sebesar 9 (24,3\%), frekwensi dan prosentase cukup sebesar 9(24,3\%), frekwensi dan prosentase kurang sebesar $10(0 \%)$. Hal ini menunjukkan bahwa selalu mendapat kelompok ketika mengerjakan tugas kelompoktermasuk dalam kategori sangat baik meskipun rata-rata item ini sebesar 3,3.

Teman-teman mengajak menjadi anggota kelompok dalam mengerjakan tugasdalam tabel diperoleh nilai perhitungan rata-rata sebesar 2,7 termasuk dalam kategori kurang jika dibandingkan dengan rata-rata keseluruhan 3. Menurut perhitungan dalam tabel, diperoleh nilai frekwensi dan prosentase sangat baik sebesar 11 (29,7\%), frekwensi dan prosentase baik sebesar 6 (16,2\%), frekwensi dan prosentase cukup sebesar $18(48,6 \%)$, frekwensi dan prosentase kurang sebesar $2(5,4 \%)$. Hal ini menunjukkan bahwa Teman-teman berbuat usil atau mengganggu termasuk dalam kategori kurang meskipun ratarata item ini sebesar 2,7 . 


\section{SIMPULAN}

Berdasarkan angket yang dibagikan di SD Negeri Ngaringan 05 Kecamatan Gandusari Kabupaten Blitar dan hasil analisis mengenai interaksi teman sebaya dapat disimpulkan, bahwa dalam interaksi teman sebaya yang meliputi: 1)Kelekatan dengan sebaya; 2) Menghabiskan banyak waktu dengan sebaya; 3) Mempunyai kelompok teman sebaya; 4) Kepercayaan tinggi pada sebaya; 5) Ada aturan yang mengikat pada pertemanan; 6) Mempengaruhi teman; 7) Keinginan identik dengan sebaya; 8) Banyak sedikit jumlah teman; 9) Suka menyendiri; 10) Menjadi pemimpin kelompok di sekolah; 11) Mendapat ajakan bemain teman; 12) Mendapat perlakuan baik teman; 13) Mendapat teman dalam tugas kelompok pada umumnya sudah terjalin dengan baik

Meskipun demikian dari data-data yang diperoleh di indikasikan bahwa masih ada beberapa aspek yang perlu ada peningkatan dalam beberapa hal, antara lain: bercerita kepada teman jika dimarahi orangtua, teman-teman suka mengejek, mempunyai geng di sekolah, tidak takut mengejek orang yang lebih dewasa ketika bersama temanteman, dilarang bermain dengan teman yang dibenci teman, mengikuti ajakan teman-teman karena takut dijauhi, ketika istirahat lebih senang di kelas, memakai pakaian atau aksesoris yang sama atau mirip dengan teman-teman kelompok bermain, ingin memiliki barang yang sama dengan teman-teman, hanya bermain dengan teman yang dekat dengan saja, ketika istirahat saya lebih senang di kelas, suka belajar sendiri daripada dengan teman-teman, teman-teman memilih menjadi ketua jika mendapatkan tugas kelompok, suka bermain sendiri di sekolah, Teman-teman suka mengejek, teman-teman mengajak menjadi anggota kelompok.

\section{SARAN}

Berdasarkan hasil yang diperoleh, dapat dipaparkan saran berkenaan dengan hasil penelitian sebagai berikut:

1. Bagi sekolah, mampu menerapkan nilai-nilai moral dan agama yang tinggi, interaksi sosial antar warga sekolahpun harus harmonis.

2. Bagi keluarga, lebih meningkatkan keberfungsian sosial sebuah keluarga dalam melaksanakan tugas kehidupan, peranan, dan fungsinya. Selain itu, keluarga diharapkan menggunakan waktu luang yang terarah dan hubungan interpersonal yang harmonis antara anak dan anggota keluarga lainnya.

Yusvidha Ernata. Anaisis Interaksi Teman Sebaya Peserta Didik Kelas V Di SDN Ngaringan 05 Kecamatan Gandusari Kabupaten Blitar 


\section{DAFTAR RUJUKAN}

Ahmadi, A.(2002). Psikologi Sosial. Jakarta: Rineka Cipta

Desmita. (2007). Psikologi Perkembangan. Bandung: Remaja Rosdakarya

John W. Santrock. (2002). Life Span Development (Perkembangan Masa Hidup). Penerjemah: Juda Damanik, dkk. Jakarta: Erlangga.

Purwitasari, Y. (2011). Pengaruh Negative Hubungan Interaksi Social Dalam Kelompok Teman Sebaya (Gang) Di Sekolah, (Online) Diakses Tanggal 2 Juni 2015. Http://Ayussoulimage.Blogspot.Com/2011/04/PengaruhNegative-Hubungan-Interaksi.Html

Salam, B. (2002). Pengantar Pedagogik Dasar-Dasar Ilmu Mendidik. Jakarta: Rineka Cipta.

Syamsu, Y. (2006). Psikologi Perkembangan Anak \& Remaja. Bandung: Remaja Rosdakarya Offset. 